\title{
Analytical Study of Tall Building with Outtrigger System with Respect to Seismic and Wind Analysis Using ETABS
}

\author{
T.Subramani ${ }^{1}$, K.Murali ${ }^{2}$ \\ $1^{*}$ Managing Director, Priyanka Associates (Civil Engineers and Valuers), Salem, TamilNadu, India. \\ ${ }^{2}$ Assistant Executive Engineer, PWD, Namakkal., TamilNadu, India. \\ *Corresponding author E-mail: tsmcivil2007@gmail.com
}

\begin{abstract}
Today the development of structural system goes beyond the unexpected level. To overcome the problems persist in the structural behavior numerous studies has routed out. On this present have a look at is targeted at the performance of multi outrigger structural system for a ten storey constructing with static and dynamic analyses of various fashions were examined the use of ETABS software program. The performance analysis of the tall building for distinctive fashions are performed to discover the surest function of outrigger gadget and belt truss with the aid of the usage of lateral loads. Time history analysis for floor movement statistics of the ten storey building version are carried out. The evaluation includes lateral displacement; storeys go with the flow and base shear for static and dynamic loading. From the acquired results the effective performance of building with outriggers are evaluated. Our project describes the structural layout of similar 10 storey the use of overall performance based totally strategies for seismic and wind movements.
\end{abstract}

Keywords:Analytical, Tall Building , Outtrigger System, Seismic and Wind Analysis, ETABS

\section{Introduction}

Development in tall buildings entails numerous compound factors as an instance money subjects, necessities, era, creation regularities and so forth. The demanding situations are greater for the dressmaker as the top of the building and constructing plan turns into complicated. Tall homes cannot be designed without taking into account the targeted tolerant of denoting elements that affect for the selection of structural device. Selfweight of the building, stay load performing, and earthquake masses and alongside wind forces are substantial elements and play essential position inside the design. Tall structures are commonly designed for residential, office or commercial use. They may be normally a response to the speedy growth of the city population and the demand by commercial enterprise sports to be as close to every different as viable. a massive part of India is at risk of unfavourable stages of seismic hazards. As a result, it's miles essential to bear in mind the seismic load for the design of high-upward push structure. The exceptional lateral load resisting structures are used in excessive-upward push building because the lateral hundreds due to earthquake area be counted of problem. These lateral forces can produce important stresses within the shape, inducing unwanted stresses inside the shape, and unwanted vibrations or cause excessive lateral sway of the structure.

\subsection{Structural Behavior of Outrigger}

In outrigger structural device the belt truss ties all the external columns at the periphery of the shape and the outrigger connect these belt trusses to the valuable middle of the structure as a result restraining the outside columns from rotation. When the shape is subjected to lateral forces, the outrigger and the columns resist the rotation of the middle and hence appreciably reduce the lateral deflection and base second. To growth stiffness movement in opposition to wind and seismic load outriggers are provided by way of the shear center with outdoors frames in tall homes. The effective depth of the structure is improved, when the outriggers are positioned. The primary cause of the structural machine is to efficaciously switch the gravity hundreds with out causing damage to the homes. The gravity masses are particularly dead load, stay load and snow load which have an effect on the tall buildings. Fig.1 shows the different type of braced frame.

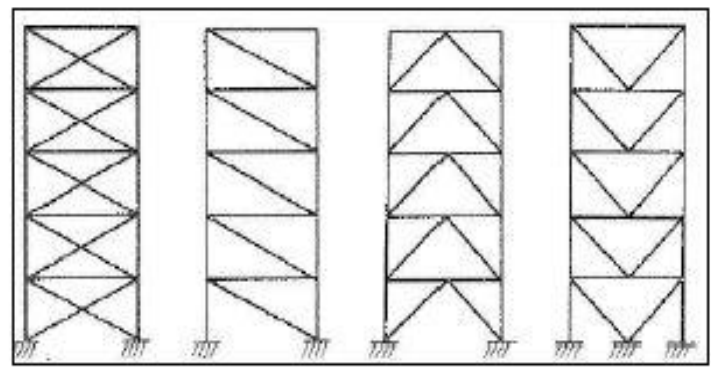

Fig.1: Different type of braced frame

\subsection{Scope and Objectives of Study}

An objective to investigate the behavior of buildings, beneath the seismic region structural overall performance of complex shaped tall buildings with structural structures which include braced tube, diagrids and outrigger systems structural performance of each system is studied. For contrast of 3 structures beneath the same seismic zone, the parameter in all the buildings is taken same. The building studied on this phase 
is a reinforced concrete moment resisting framed building designed for gravity masses.

\section{Methodology}

Fig.2 shows the methodology of the study

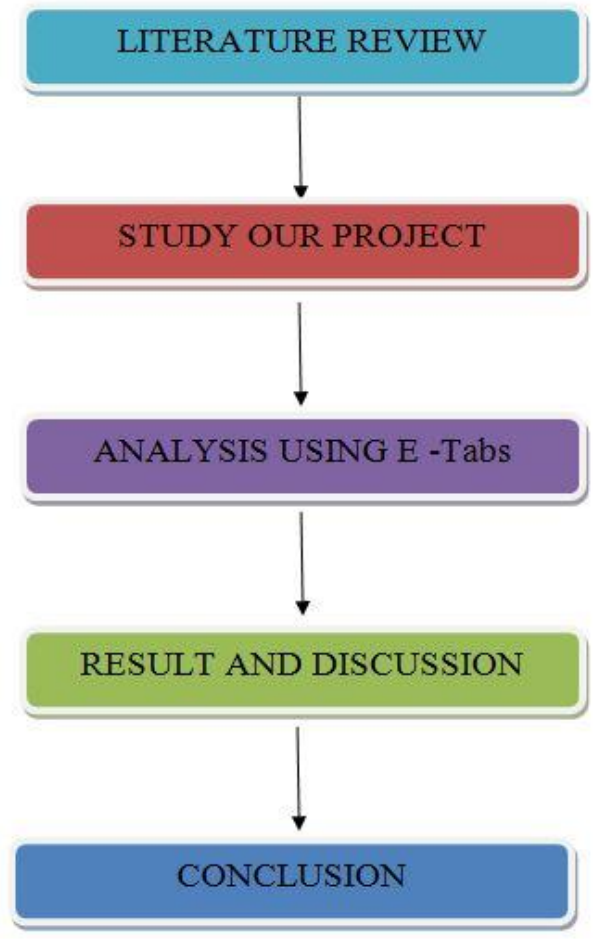

Fig.2: Methodology

\section{High Rise Building}

This examines starts off evolved with an explanation of the construction process to clarify the scope of the document. that is followed by a short phase about the definition and history of high upward push systems. Finally, distinct structural systems used in high-upward push homes are quick explained and illustrated.

\section{Outrigger Structural System}

In this concept, "outrigger" trusses enlarge from a lateral loadresisting core to columns on the exterior of the building. The important idea in conceptualizing the structural system for an arrow tall constructing is to think about it as a beam cantilevering from the earth, the laterally directed pressure generated, both because of wind blowing in opposition to the constructing or because of the inertia forces triggered by way of floor shaking, has a tendency both to snap it (shear), and push it over (bending), consequently, the constructing need to have a machine to face up to shear in addition to bending. in resisting shear forces, the building ought to not spoil through shearing off and need to not pressure beyond the limit of elastic recuperation, whilst an outrigger-braced building deflects beneath wind or seismic load, the outrigger which connects to the core wall and the outside columns/shear walls, makes the complete device to act as a unit in resisting the lateral pressure, the number one end result of the outrigger trusses is the development of axial forces inside the outside columns because of lateral load movement.

\subsection{Concept of Outrigger}

Present use outriggers to assist resist the wind forces of their sails. Just like the ship, the core in the tall building may be related to the mast of the deliver, the outrigger performing like the spreaders and the exterior columns just like the remains or shroud of the ship. The slim boat will overturn whilst toss with the aid of surprising wave however the small quantity of flotation (i.e. upward resistance) or weight (i.e. downward resistance) performing via outrigger is sufficient to avoid overturning. In the same manner building outrigger are connected to perimeter columns capable of resisting upward and downward forces can greatly improve the constructing resistance.

\section{Software}

\subsection{Program Levels and Features}

In this present work ETABS is used to analysis the shear wall structure of $\mathrm{G}+29$ considering the gravity and lateral loads.

\subsection{Loads}

There are many different kinds of actions on a building. The structural system must resist both vertical and lateral loads. Different loads are listed below.

\subsubsection{Permanent Loads}

Self weight from structural members, non-structural members and self-weight from installations.

\subsubsection{Imposed Loads}

Loads from occupants, furniture and snow.

\subsubsection{Horizontal Load}

Wind load is acting as a horizontal load.

\subsubsection{Other Loads}

Seismic loads and accidental loads. When choosing the characteristic values of the vertical live loads. When designing high rise buildings there are some specific requirements listed in Indian code.

\section{Structural Modeling}

The ETABS software is one in which we are able to are expecting the dynamic and static analysis of the hundreds which act on the structural participants. It can are expecting the geometric nonlinear behavior of area frames beneath static or dynamic loadings, taking into consideration both geometric nonlinearity and material inelasticity. Buildings of 15 storied are taken and their structural conduct is as compared beneath seismic zone $\mathrm{v}$ using nonlinear time history evaluation. Table 1 shows the storey data.

Table 2 shows the storey data. 
Table 1: Storey data

\begin{tabular}{|c|c|c|c|c|}
\hline Name & $\begin{array}{l}\text { Height } \\
\mathrm{mm}\end{array}$ & $\begin{array}{c}\text { Eleration } \\
\mathrm{mm}\end{array}$ & $\begin{array}{l}\text { Alaster } \\
\text { Story }\end{array}$ & $\begin{array}{c}\text { Similar } \\
\text { To }\end{array}$ \\
\hline Story30 & 4000 & 120000 & No & Non: \\
\hline Story 19 & 4000 & 116000 & No & Nons \\
\hline Story 23 & 4000 & 112000 & No & None \\
\hline Story 27 & 4000 & 108000 & No & Non: \\
\hline Story 26 & 4000 & 104000 & No & None \\
\hline Story 25 & 4000 & 100000 & No & None \\
\hline Story 24 & 4000 & 96000 & No & Non: \\
\hline Story 23 & 4000 & 92000 & No & None \\
\hline Story 22 & 4000 & 85000 & No & None \\
\hline Story 21 & 4000 & 84000 & No & None \\
\hline Story 20 & 4000 & 80000 & No & None \\
\hline Story 19 & 4000 & 76000 & No & None \\
\hline Story 18 & 4000 & 72000 & No & None \\
\hline Story 17 & 4000 & 65000 & No & None \\
\hline Stary 16 & 4000 & 64000 & No & None \\
\hline Story 15 & 4000 & 60000 & No & None \\
\hline Story 14 & 4000 & 36000 & No & None \\
\hline Story 13 & 4000 & 32000 & No & None \\
\hline Story 12 & 4000 & 45000 & No & None \\
\hline Storyll & 4000 & 44000 & No & None \\
\hline Story 10 & 4000 & 40000 & No & None \\
\hline \$tor 9 & 4000 & 36000 & No & None \\
\hline Story & 4000 & 32000 & No & None \\
\hline Story? & 4000 & 25000 & No & None \\
\hline Stargs & 4000 & 24000 & No & None \\
\hline Story 5 & 4000 & 20000 & No & None \\
\hline Stary 4 & 4000 & 16000 & No & None \\
\hline Story ${ }^{3}$ & 4000 & 12000 & No & None \\
\hline Stor 2 & 4000 & 8000 & No & Non: \\
\hline Stan 1 & 4000 & 4000 & No & None \\
\hline Base & 0 & 0 & No & Nons \\
\hline
\end{tabular}

The ETABS software is one in which we are able to are expecting the dynamic and static analysis of the hundreds which act on the structural participants. It can are expecting the geometric nonlinear behavior of area frames beneath static or dynamic loadings, taking into consideration both geometric nonlinearity and material inelasticity. Buildings of 15 storied are taken and their structural conduct is as compared beneath seismic zone $\mathrm{v}$ using nonlinear time history evaluation. Table 1 shows the storey data.

\subsection{Loads}

This area provides loading information as applied to the model.

\subsubsection{Load Patterns}

Table 2 shows the load patterns.

Table 2: Load Patterns

\begin{tabular}{|c|c|c|c|}
\hline Name & Type & $\begin{array}{l}\text { Self-Weight } \\
\text { Multiplier }\end{array}$ & Auto Load \\
\hline Dezd & Dowd & 1 & \\
\hline Live & Live & 0 & \\
\hline Wind & Wind & 0 & $\begin{array}{l}\text { Indsan } \\
\text { Is875:1987 }\end{array}$ \\
\hline Sotsmic & Earsmic & 0 & 1818932002 \\
\hline
\end{tabular}

\subsection{Load Cases}

Table 3 shows the load cases summary
Table 3: Load Cases - Summary

\begin{tabular}{|c|c|}
\hline Name & Type \\
\hline Dead & Linear Static \\
\hline Live & Linear Static \\
\hline Wind & Linear Static \\
\hline Seismic & Linear Static \\
\hline
\end{tabular}

\section{Analysis Results}

This area provides analysis results.

\subsection{Structure Results}

Table 4 shows the base reactions.

Table 4: Base Reactions

\begin{tabular}{|c|c|c|c|c|c|c|}
\hline Load & $\mathrm{FX}$ & FY & FZ & $\mathbf{M X}$ & $\mathbf{M Y}$ & $\mathbf{M Z}$ \\
\hline Case/Combo & $\mathrm{kN}$ & $\mathrm{kND}$ & $\mathrm{kN}$ & $\mathrm{kN}-\mathrm{m}$ & $\mathrm{kN}-\mathrm{m}$ & $\mathrm{kN}-\mathrm{m}$ \\
\hline Dead & $D$ & 0 & -304530 & 7308729 & 7308729 & 0 \\
\hline Live & 0 & 0 & 0 & 0 & 0 & 0 \\
\hline Wind 1 & 0 & 0 & 0 & 0 & 0 & 0 \\
\hline Wind 2 & 0 & 0 & 0 & 0 & 0 & 0 \\
\hline Seismic 1 & -15870.4535 & 0 & 0 & 0 & -1440752 & -380891 \\
\hline Seismic 2 & 0 & 15870.4535 & 0 & 1440752 & 0 & -380891 \\
\hline Seismic 3 & -15870.4535 & 0 & 0 & 0 & -1440752 & -380891 \\
\hline Seismic 4 & 0 & 15870.4535 & 0 & 1440752 & 0 & -380891 \\
\hline Seismic 5 & -15870.4535 & 0 & 0 & 0 & -1440752 & -380891 \\
\hline Seismic 6 & 0 & 15870.4535 & 0 & 1440752 & 0 & -380891 \\
\hline Res Max & 162355.1069 & 0.0434 & 0 & 0.2948 & 11889792 & 3896521 \\
\hline $\begin{array}{c}\text { Time history } \\
\text { Max }\end{array}$ & 7558.0958 & 0.002 & $\begin{array}{c}2868.85 \\
11\end{array}$ & 64489.7401 & 567304.7572 & $\begin{array}{c}181394.259 \\
8\end{array}$ \\
\hline $\begin{array}{c}\text { Time history } \\
\text { Min }\end{array}$ & -7549.3119 & -0.0024 & $\begin{array}{c}2687.07 \\
19\end{array}$ & -68852.4323 & -579763 & -181183 \\
\hline Buckling 1 & 0.0001 & -35.7921 & $\begin{array}{c}-3.012 \mathrm{E}- \\
06\end{array}$ & -1010.7972 & 0.0081 & -333.6386 \\
\hline Buckling 2 & -0.001 & -1.9014 & $\begin{array}{c}1.158 \mathrm{E}- \\
05\end{array}$ & -136.7027 & 0.006 & 99.7719 \\
\hline Buckling 3 & 42.0482 & -0.0013 & -0.2395 & 5.7501 & -3076.543 & 1009.1572 \\
\hline Buckling 4 & -0.0006 & 23.8042 & $\begin{array}{c}2.85 \mathrm{E}- \\
06\end{array}$ & 2471.0655 & 0.0065 & 415.9415 \\
\hline
\end{tabular}

Fig. 3 shows the $3 \mathrm{D}$ rendering view

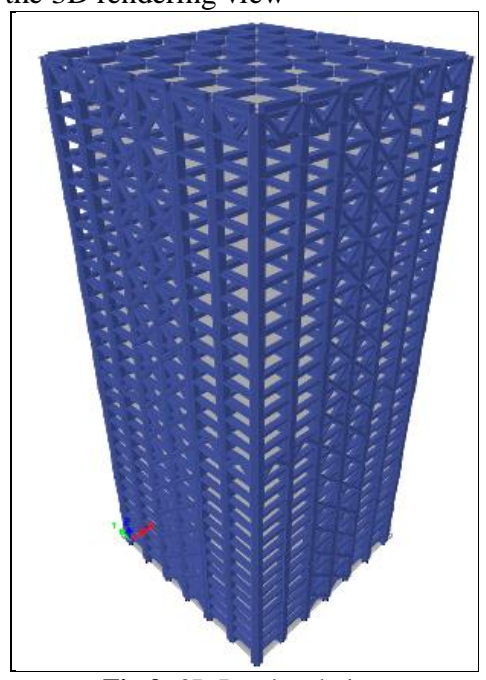

Fig.3: 3D Rendered view

Fig.4 shows the Bending moment diagram for Elevation 


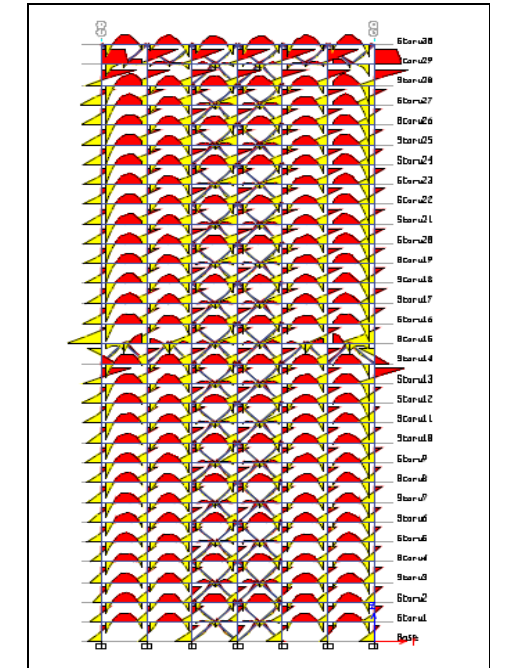

Fig.4: Bending moment diagram for Elevation

Fig.5 shows the Shear force diagram in Plan

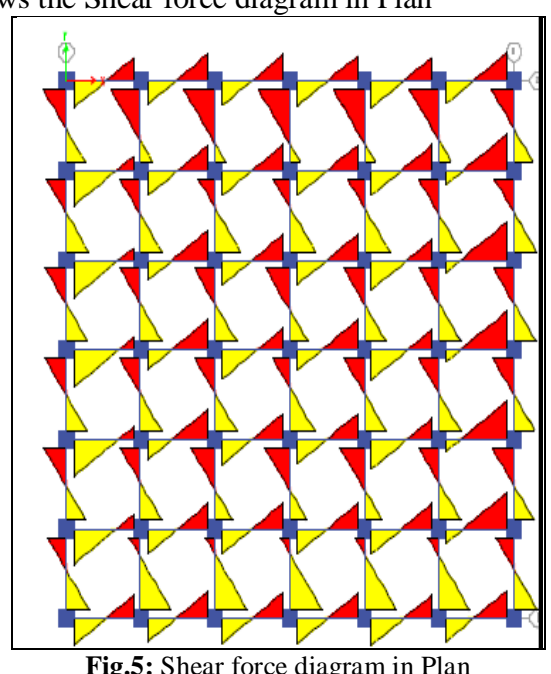

Fig.5: Shear force diagram in Plan

Fig. 6 shows the Bending moment and shear force diagram for Individual Beam

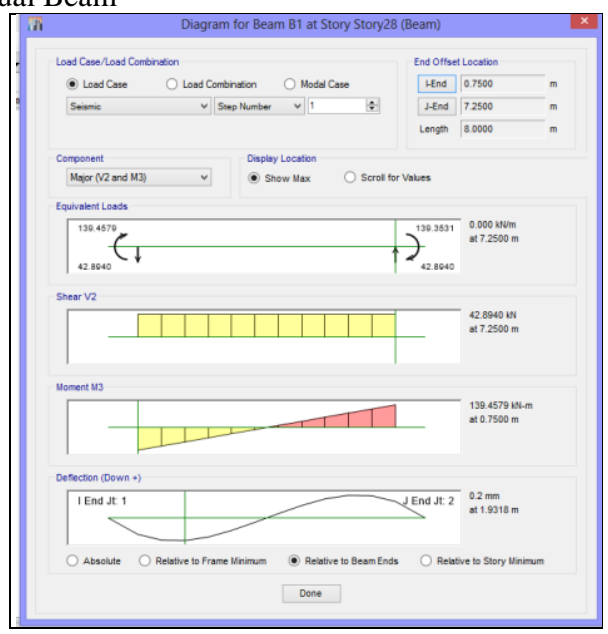

Fig.6: Bending moment and shear force diagram for Individual Beam

\subsection{Story Response Plot}

Fig.7 shows the storey displacement.

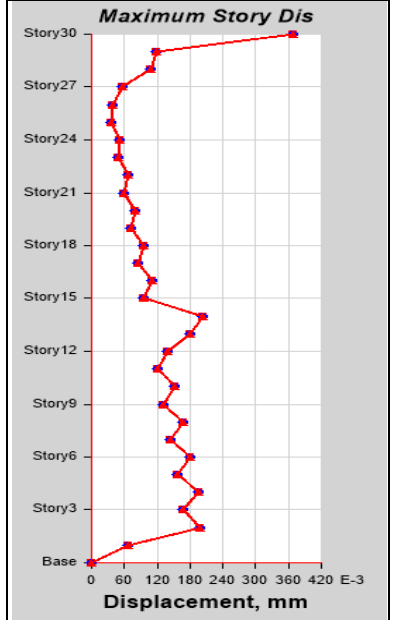

Fig.7: Story displacement

Fig. 8 shows the storey drift.

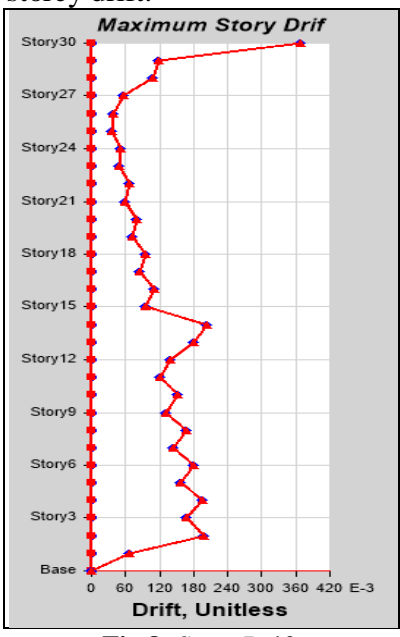

Fig.8: Story Drift

Fig.9 shows the storey overturning.

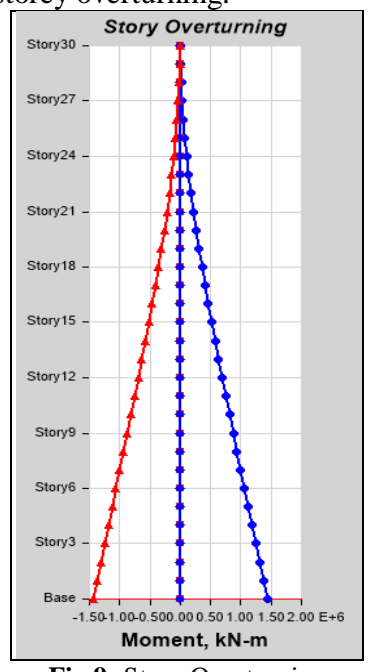

Fig.9: Story Overturning

\subsection{Response Spectrum Analysis}

Fig.10 shows the spectral displacement. 


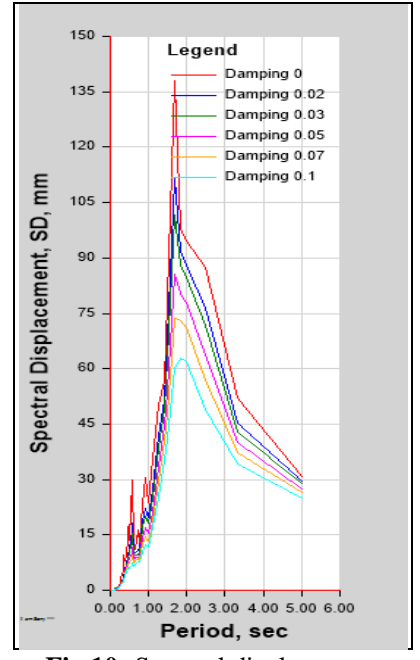

Fig.10: Spectral displacement

Fig.11 shows the storey velocity.

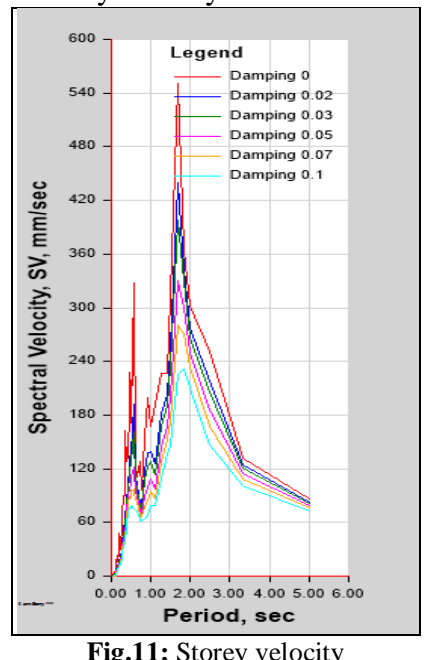

Fig.11: Storey velocity

\section{Conclusion}

The specific parameters which include storey drifts, base shear, modal intervals of buildings are evaluated the use of nonlinear time records evaluation in e-tabs. The use of outrigger structural method will increase the total stiffness of the structure via connecting the building core to the remote column and makes the whole device to behave as a one unit in resisting the total lateral load. A framed tube system with inner tubes is examined using orthotropic container beam analogy method which is considered for flexural and shears lag effects. The overall results recommended that bundled tube is great seismic manipulate for more excessive-upward push symmetric buildings. as time records is realistic technique, used for seismic evaluation, it gives a maximum higher check to the protection of systems analyzed and designed by way of technique specified by way of IS code.

\section{References}

[1] T.Subramani, J.Jayalakshmi , " Analytical Investigation Of Bonded Glass Fibre Reinforced Polymer Sheets With Reinforced Concrete Beam Using Ansys" , International Journal of Application or Innovation in Engineering \& Management (IJAIEM), Volume 4, Issue 5, pp. 105-112, 2015

[2] T.Subramani. , S.Vishnupriya, "Finite Element Analysis of a Natural Fiber (Maize) Composite Beam”, International Journal of Modern Engineering Research, Volume. 4, Issue. 6 (Version 1), pp 1-7, 2014,
T.Subramani., R.Senthil Kumar, "Modelling and Analysis of Hybrid Composite Joint Using Fem in ANSYS", International Journal of Modern Engineering Research, Volume 4, Issue 6 (Version 1), pp 41- 46, 2014.

[4] T.Subramani, S.Sharmila, "Prediction of Deflection and Stresses of Laminated Composite Plate with Artificial Neural Network Aid", International Journal of Modern Engineering Research, Volume 4, Issue 6 (Version 1), pp 51 -58, 2014.

[5] T.Subramani., S.Sundar, M.Senthilkumar, "Investigation of the Behaviour for Reinforced Concrete Beam Using Non Linear Three Dimensional Finite Elements", International Journal of Modern Engineering Research, Volume. 4, Issue. 6 (Version 2), pp $13-18,2014$,

[6] T.Subramani, A.Arul, "Design And Analysis Of Hybrid Composite Lap Joint Using Fem" International Journal of Engineering Research and Applications, Volume. 4, Issue. 6 (Version 5), pp 289- 295, 2014.

[7] T.Subramani., J.Jothi,, M.Kavitha "Earthquake Analysis Of Structure By Base Isolation Technique In SAP", International Journal of Engineering Research and Applications, Volume. 4, Issue. 6 (Version 5), pp 296 - 305, 2014.

[8] T.Subramani., R.Manivannan.R, M.Kavitha, "Crack Identification In Reinforced Concrete Beams Using Ansys Software" ,International Journal of Engineering Research and Applications, Volume. 4, Issue. 6 (Version 6), pp 133 - 141, 2014.

[9] T.Subramani., Reni Kuruvilla, J.Jayalakshmi., "Nonlinear Analysis Of Reinforced Concrete Column With Fiber Reinforced Polymer Bars" International Journal of Engineering Research and Applications Volume. 4, Issue. 6 (Version 5), pp 306- 316, 2014

[10] T.Subramani, D.Sakthi Kumar, S.Badrinarayanan. "Fem Modelling And Analysis Of Reinforced Concrete Section With Light Weight Blocks Infill " International Journal of Engineering Research and Applications, Volume. 4, Issue. 6 (Version 6), pp 142 - 149, 2014.

[11] T.Subramani, B.Saravanan., J.Jayalakshmi., "Dynamic Analysis Of Flanged Shear Wall Using Staad Pro", International Journal of Engineering Research and Applications, Volume. 4, Issue. 6 (Version 6), pp 150 - 155, 2014.

[12] T.Subramani, M.Subramani., K.Prasath.,"Analysis Of Three Dimensional Horizontal Reinforced Concrete Curved Beam Using Ansys" International Journal of Engineering Research and Applications, Volume. 4, Issue. 6 (Version 6), pp 156 - 161, 2014.

[13] T.Subramani., K.Bharathi Devi., M.S.Saravanan., Suboth, Analysis Of RC Structures Subject To Vibration By Using Ansys," International Journal of Engineering Research and Applications Vol. 4, Issue 12(Version 5), pp.45-54, 2014.

[14] T.Subramani., K.Bharathi Devi., M.S.Saravanan., Suboth Thomas, "Analysis Of Seismic Performance Of Rock Block Structures With STAAD Pro International Journal of Engineering Research and Applications Vol. 4, Issue 12(Version 5), pp.55- 68, 2014.

[15] T.Subramani., T.Krishnan., M.S.Saravanan.M, Suboth Thomas, "Finite Element Modeling On Behaviour Of Reinforced Concrete Beam Column Joints Retrofitted With CFRP Sheets Using Ansys" International Journal of Engineering Research and Applications Vol. 4, Issue 12(Version 5), pp.6976, 2014

[16] T.Subramani., S.Krishnan., M.S.Saravanan.M, Suboth Thomas "Analysis Of Retrofitting Non-Linear Finite Element Of RCC Beam And Column Using Ansys” International Journal of Engineering Research and Applications, Vol. 4, Issue 12(Version 5), pp.77-87, 2014.

[17] T.Subramani, J.Jayalakshmi , " Analytical Investigation Of Bonded Glass Fibre Reinforced Polymer Sheets With Reinforced Concrete Beam Using Ansys" , International Journal of Application or Innovation in Engineering \& Management (IJAIEM), Volume 4, Issue 5, pp. 105-112, 2015

[18] T.Subramani and M.Kavitha, "Analysis Of Reliability Of Steel Frame Systems With Semi-Rigid Connections Using Numerical Method And Finite Element Analysis", International Journal of Applied Engineering Research (IJAER), Volume 10, Number 38,Special Issues, pp.28240-28246, 2015.

[19] T.Subramani, M.S.Saravanan, "Analysis Of Non Linear Reinforced And Post Tensioned Concrete Beams Using ANSYS", International Journal of Applied Engineering 
Research (IJAER) International Journal of Applied Engineering Research (IJAER), Volume 10, Number 38 Special Issues, pp.28247-28252, 2015

[20] T.Subramani, K.Balamurugan, " Finite Element Anaylsis Of Composite Element For FRP Reinforced Concrete Slab By Using ANSYS", International Journal of Application or Innovation in Engineering \& Management (IJAIEM), Volume 5, Issue 5, pp. 076-084, 2016.

[21] T.Subramani, V.Kanian Poonkundran, " Prefabricated Multistory Structure Exposure To Engineering Seismicity By Using SAP" , International Journal of Application or Innovation in Engineering \& Management (IJAIEM), Volume 5, Issue 5, pp. 123-131, 2016.

[22] T.Subramani, A.Kumaravel, " Analysis Of Polymer Fibre Reinforced Concrete Pavements By Using ANSYS", International Journal of Application or Innovation in Engineering \& Management (IJAIEM), Volume 5, Issue 5, pp. 132-139, 2016

[23] T.Subramani, R.Praburaj, " Pushover Anaylsis Of Retrofitted Reinforced Concrete Buildings By Using SAP" , International Journal of Application or Innovation in Engineering \& Management (IJAIEM), Volume 5, Issue 5, pp. 140-147, 2016 T.Subramani, M.Senthilkumar, " Finite Element Anaylsis Of RC Beams With Externally Bonded Simcon Laminates By Using ANSYS" , International Journal of Application or Innovation in Engineering \& Management (IJAIEM), Volume 5, Issue 5, pp. 148-155, 2016

[24] T.Subramani, R.Vasanthi, " Earth Quake Resistant Building Using SAP" , International Journal of Application or Innovation in Engineering \& Management (IJAIEM), Volume 5, Issue 5, pp. 173-181, 2016 .

[25] T.Subramani, A.Selvam, " Studies On Economical Configuration Of RCC And Prestressed Shell Roofs By Using ANSYS " , International Journal of Application or Innovation in Engineering \& Management (IJAIEM), Volume 5, Issue 5, pp. 182-191, 2016

[26] T.Subramani, A.Anbuchezian, " Experimental Investigation On Flexural Behavior Of Folded Ferro Cement Panels " , International Journal of Application or Innovation in Engineering \& Management (IJAIEM), Volume 6, Issue 3, March 2017, pp. 045-049, ISSN 2319 - 4847.

[27] T.Subramani, A. Fizoor Rahman, " An Experimental Study On The Properties Of Pet Fibre Reinforced Concrete ", International Journal of Application or Innovation in Engineering \& Management (IJAIEM), Volume 6, Issue 3, March 2017, pp. 058-066, ISSN 2319 - 4847.

[28] T.Subramani, S.Poongothai, S.Priyanka, " Analytical Study Of T Beam Column Joint Using FEM Software " , International Journal of Emerging Trends \& Technology in Computer Science (IJETTCS), Volume 6, Issue 3, May - June 2017, pp. 148-156, ISSN 2278-6856

[29] T.Subramani, R.Ganapathy,V.Manoharan, M.Balamurugan R.Murugesan, " Design And Analysis Of Light Weight Concrete Building Using ETAB With Respect To Dynamic Loading " , International Journal of Emerging Trends \& Technology in Computer Science (IJETTCS), Volume 6, Issue 3, May - June 2017 , pp. 252-258, ISSN 2278-6856.

[30] T.Subramani, A.Mohammed Ali, R.Karthikeyan, E.Panner Selvan, K.Periyasamy , " Analytical Study Of T-Beam Using ANSYS " , International Journal of Emerging Trends \& Technology in Computer Science (IJETTCS), Volume 6, Issue 3, May - June 2017, pp. 259-266, ISSN 2278-6856.

[31] T.Subramani, V.Kalaivanan, S.Priyaranjithkumar, P.Sasikumar, P.Vinoth Kumar, " Design And Analysis Of Multistorey Building With Respect To Seismic Loads Using ETABS ", International Journal of Emerging Trends \& Technology in Computer Science (IJETTCS), Volume 6, Issue 3, May - June 2017 , pp. 267-274, ISSN 2278-6856. 